УДК 32.019.5:004.9

https://doi.org/10.34142/24130060.2020.20.1.16

\title{
УКРАЇНСЬКИЙ ЦИФРОВИЙ ПОЛІТИЧНИЙ ДИСКУРС В УМОВАХ «ГІБРИДНОЇ МЕДІАСИСТЕМИ»
}

\author{
Н. О. Стеблина \\ Донецький національний університет імені Василя Стуса
}

У сучасному ичифровому політичному дискурсі повідомлення поширюються в умовах функиіонування «гібридної медіасистеми»: за допомогою як традиційних каналів (мас-медіа, прес-служби), так і нових (соимережі). У статті на матеріалі «Украӥнської правди» визначається, щзо традиційні канали (ЗМI) - значно переважають над рештою. Проте у ЗМІ найбільше використовуються передруки, а ексклюзивні повідомлення під час важливих для країни подій практично не відіграють значної ролі. Повідомлення пресслужб вийшли на перший план тільки двічі, соимережі-посідали третю позицію.

Ключові слова: цифровий політичний дискурс, Украӥна, «гібридна медіасистема», «Українська правда», сочмережі.

\section{УКРАИНСКИЙ ЦИФРОВОЙ ПОЛИТИЧЕСКИЙ ДИСКУРС В УСЛОВИЯХ «ГИБРИДНОЙ МЕДИАСИСТЕМЫ»}

\author{
Н. А. Стеблина
}

В современном циифровом политическом дискурсе сообщения распространяются 8 условиях функиионирования «гибридной медиасистемы»»: при помощи как традищионных каналов (масс-медиа, пресс-службы), так и новых (соисети). В статье на материале «Украинской правдыл» определяется, что традииионные канальы (СМИ) - имеют значительное преимущество над остальными. Но в СМИ наиболее представлень перепечатки, а эксклюзивные сообщения во время важных событий практически не имеют значительной роли. Сообщения пресс-служб вышли на первый план только дважды, соцсети - занимали третью позицию.

Ключевые слова: циифровой политический дискурс, Украина, «гибридная медиасистема», «Украинская правда», соисети.

\section{UKRAINIAN DIGITAL POLITICAL DISCOURSE IN THE REALITY OF «HYBRID MEDIA SYSTEM»}

\section{N. Steblyna}

Nowadays political texts are disseminating in the reality of digital political discourse and «hybrid media system» (Chadwick), where both traditional channels (mass media, press services) and new ones (social networks) are represented. Thus, it's important to understand the dynamics of the channels functioning. In order to do so, political texts from one of the leading Ukrainian online mass media («Ukrains’ka Pravda») are content analyzed (25 October - 24 December 2018). A Python computer program (regular expressions) was designed and used for this purpose.

(C) Н.О. Стеблина, 2020 
In the Ukrainian digital political discourse mass media are widely used, and the number of reprints from local, all-Ukrainian and international news sites is the largest. As a rule, during the weekends the percentage of reprints grows. However, exclusive news items usage is minimal, and there is no significant dynamics during important events for the national agenda. Pressservices were exploited more often, than mass-media, reprints only twice: during the Azov crisis ( $25^{\text {th }}$ of November) and the day before the Unification council of the Eastern Orthodox churches of Ukraine. The results demonstrates the reality of digital discourse in the circumstances of information overflow: the list of mass-media, used for the reprints, contains about 500 positions. And press-services' texts may not be both: salient and influential for shaping the agenda. Social networks (Facebook and Twitter were studied) are on the third position. There were only three days, when the usage of the networks and press services was almost the same: $29^{\text {th }}$ of October (breaking international events plane crash and a terrorist attack), $4^{\text {th }}$ of November (death of Ukrainian activist) and $30^{\text {th }}$ of November (Azov crisis discussion). And, non-elite political actors were represented only in the second case.

Keywords: digital political discourse, Ukraine, «hybrid media system», «Ukrains’ka Pravda», social networks.

Постановка проблеми. В умовах «гібридної медіасистеми» (Chadwick, 2011) у політичному дискурсі використовуються традиційні опосередковані та нові - прямі - канали взаємодії із аудиторією. За прогнозами поступово опосередковані канали (мас-медіа, прес-служби) мають бути замінені прямими (соціальні мережі, месенджери, веб-сайти, блоги та ін.). Від деяких українських чиновників уже чуємо, що ЗМІ їм «не потрібні, щоб спілкуватися із суспільством» (censor.net.ua). Тим не менш, поки що саме традиційні канали взаємодії найбільш затребувані. А отже, важливо зрозуміти, як саме функціонує цифровий політичний дискурс за таких умов і якими є показники використання різних каналів взаємодії із аудиторією. При цьому важливо врахувати: якщо й справді в найближчому майбутньому 3МІ «вийдуть із гри» і не будуть активними учасниками політичної взаємодії у дискурсі, можемо говорити про зовсім інший розподіл сил у ньому. Адже саме 3МІ виконували функції контролю та критики або ж відігравали у політичному дискурсі роль каталізатора суспільного діалогу (Shtromaiier, 2008; Iggers, 1999; Flakh, 2015). Тож зараз маємо зрозуміти відповідь на питання: якщо ЗМІ не будуть репрезентовані у цифровому політичному дискурсі, хто саме і яким чином виконуватиме ці функції.

Аналіз актуальних досліджень. ЗМІ поступово поступаються соціальним мережам своєю роллю генератора новин. Цьому сприяє ціла 
низка факторів, про які зазначають дослідники, називаючи це явище «кризою журналістики», яка, відповідно, пов’язана і з «кризою демократії» (Suárez, 2018). 3-поміж цих факторів: фінансові (Iggers, 1999), організаційні (Deivis, 2011) та технологічні (Deuze, 2004; Steensen, 2011). При цьому, як зазначають у Columbia Journalism Review, якщо фінансові та технологічні проблеми будуть вирішені, це ще не означає, що криза зникне (Gibson, 2017).

Існує цілий корпус досліджень щодо змін у політичній комунікації під впливом соціальних мереж. Вважається, що сьогодні вони стали неодмінною складовою передвиборчої боротьби та політичної взаємодії загалом і суттєво змінюють іï (Bossetta, 2018). 3-поміж переваг соціальних мереж називають як широкий потенціал до активізму та соціальної мобілізації (Villar \& María, 2019), так і можливість впливу на вибори (Schneiker, 2019; Spierings \& Jacobs, 2019). Твіттер, Фейсбук та Інстаграм також набирають все більше популярності через те, що є дуже доступними (Schneiker, 2019), безкоштовними для поширення повідомлень, простими й зрозумілими щодо використання (Matuszewski \& Szabó, 2019), дають можливість напряму звертатися або ж взаємодіяти із широкими аудиторіями (Pérez-Curiel \& Naharro, 2019). Важливо також, що соцмережі ставлять під питання модель 3MI як «гейткіпера» (Stetka \& Surowiec, 2019), тож тепер 3МI більше не контролюють, не обмежують, не добирають політичну інформацію, яка потім буде доступна аудиторії. При цьому ЗМІ продовжують залежати від політичної інформації і просто перепубліковують популярні твіти або ж оновлення статусів у Фейсбуці, обробка цих повідомлень, як правило мінімальна (Broersma \& Graham, 2013; Heiss, von Sikorski, \& Matthes, 2019; López-Rabadán \& Mellado, 2019).

Тим не менш, переважна більшість досліджень змін у політичному дискурсі, які відбуваються під впливом соцмереж, стосується саме західних 3МІ. Але, говорячи про цифровізацію дискурсу, й український досвід важливо врахувати. Адже соціальні мережі в нашій країні активно використовувалися під час соціальних зрушень (Свромайдан та ін. протести, 
акції, флешмоби), за часів президентства П. Порошенка практично усі державні інституції запустили свої акаунти у Твіттері та Фейсбуці; Інстаграм активно використовував новообраний президент В. Зеленський та інші політики. До того ж, Україна протистоїть російській агресії, яка має потужну інформаційну складову, i велика частина пропагандистського контенту поширюється саме через соцмережі.

Саме тому мета статті - визначити, як саме у цифровому політичному дискурсі України репрезентовані повідомлення, що поширювалися через опосередковані (мас-медіа, прес-служби) та прямі (соцмережі) канали. Окрім цього, з’ясуємо, яким є відсоток повідомлень, що створювалися самими ЗМІ (ексклюзив). Матеріалом для дослідження стали публікації електронного видання «Українська правда» за 25 жовтня - 25 грудня 2018 р. Нагадаємо, що саме у цей період сталася так звана «Азовська криза» - 25 листопада російські прикордонники атакували українські кораблі, захопивши у полон українських військових моряків. Як реакцію на цей акт агресії в Україні було запроваджено воєнний стан. У цей же період 4 листопада померла активістка Катерина Гандзюк, що призвело до хвилі флешмобів, що вимагали знайти замовників нападу на неї. Також 15 грудня відбувся Об’єднавчий Собор українських православних церков. Припускаємо, що усі ці події мали вплинути на цифровий політичний дискурс, зокрема у плані використання у ньому різних каналів для поширення інформації. Тож можливо буде відстежити, як саме і з якою інтенсивністю вони використовувалися.

Дані для дослідження збиралися за допомогою комп’ютерної програми, написаної мовою Python. Згадки про різні канали передачі інформації визначалися через низку регулярних виразів, наприклад:

- «Про це $[\Pi] \backslash w+[$ еєь $] \backslash s+\backslash "\left([\backslash s \backslash S]^{*} ?\right) \backslash " » \quad$ (Про повідомляє/повідомляють/пише (власна назва із лапками чи без);

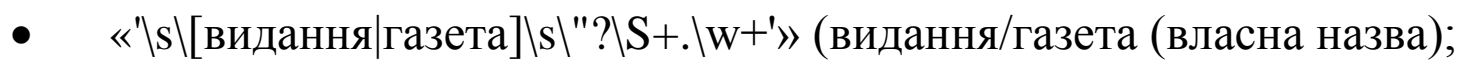

- «[пов|інф].*?(прес.служб. $\left.\backslash \mathrm{s} \backslash \mathrm{w}^{+} . \mathrm{w}^{+}\right) » \quad$ (повідомляє/інформує пресслужба); 


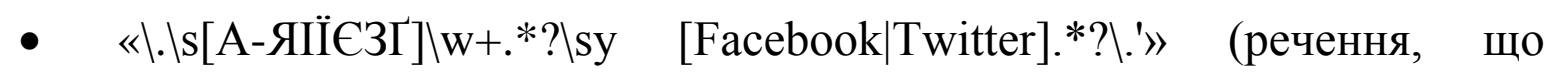
містить вираз «у Facebook/Twitter».

Виклад основного матеріалу. На основі проаналізованого матеріалу бачимо, що український цифровий політичний дискурс справді є гібридним, проте не можна сказати, що саме повідомлення із соціальних мереж переважають (див. мал. 1).

Мал. 1. Канали передачі інформації в украӥнському цифровому політичному дискурсі (Українська правда, 25 жовтня - 25 грудня 2018 р.)

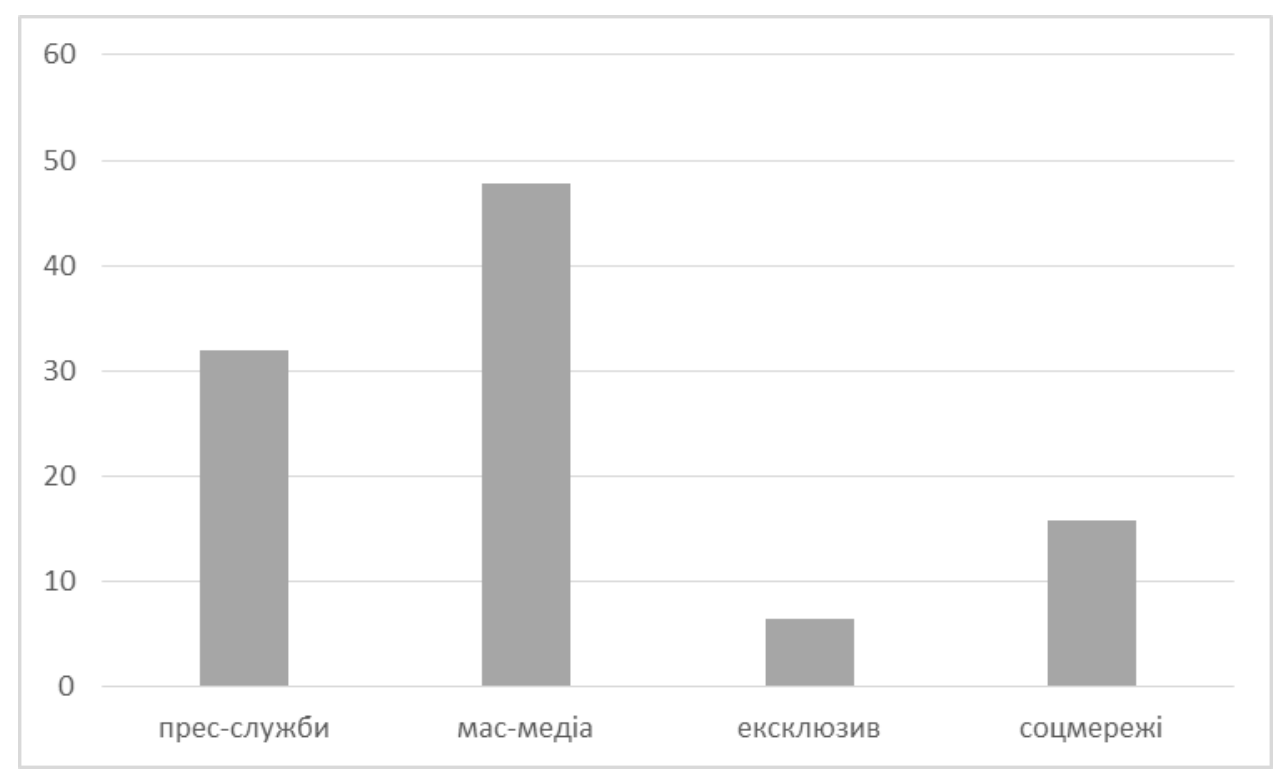

Навпаки, соцмережі посідають передостаннє місце, і є набагато менш затребуваними, ніж прес-служби та передруки з інших 3МІ (на мал. 1 вказано середні значення (медіана)). Тож поки що ми можемо зафіксувати зростання кількості передруків у ЗМІ (раніше нами був зафіксований зв'язок між кількістю повідомлень та відсотками передруків: чим більший обсяг інформації, тим більше передруків і менше ексклюзивної інформації).

Ось яку картину отримуємо, якщо проаналізуємо динаміку використання різних каналів передачі інформації по днях (мал. 2). 
Мал. 2.

Динаміка використання різних каналів передачі інформачії в українському uзифровому політичному дискурсі (Украӥнська правда, 25 жовтня - 25 грудня 2018 р.)

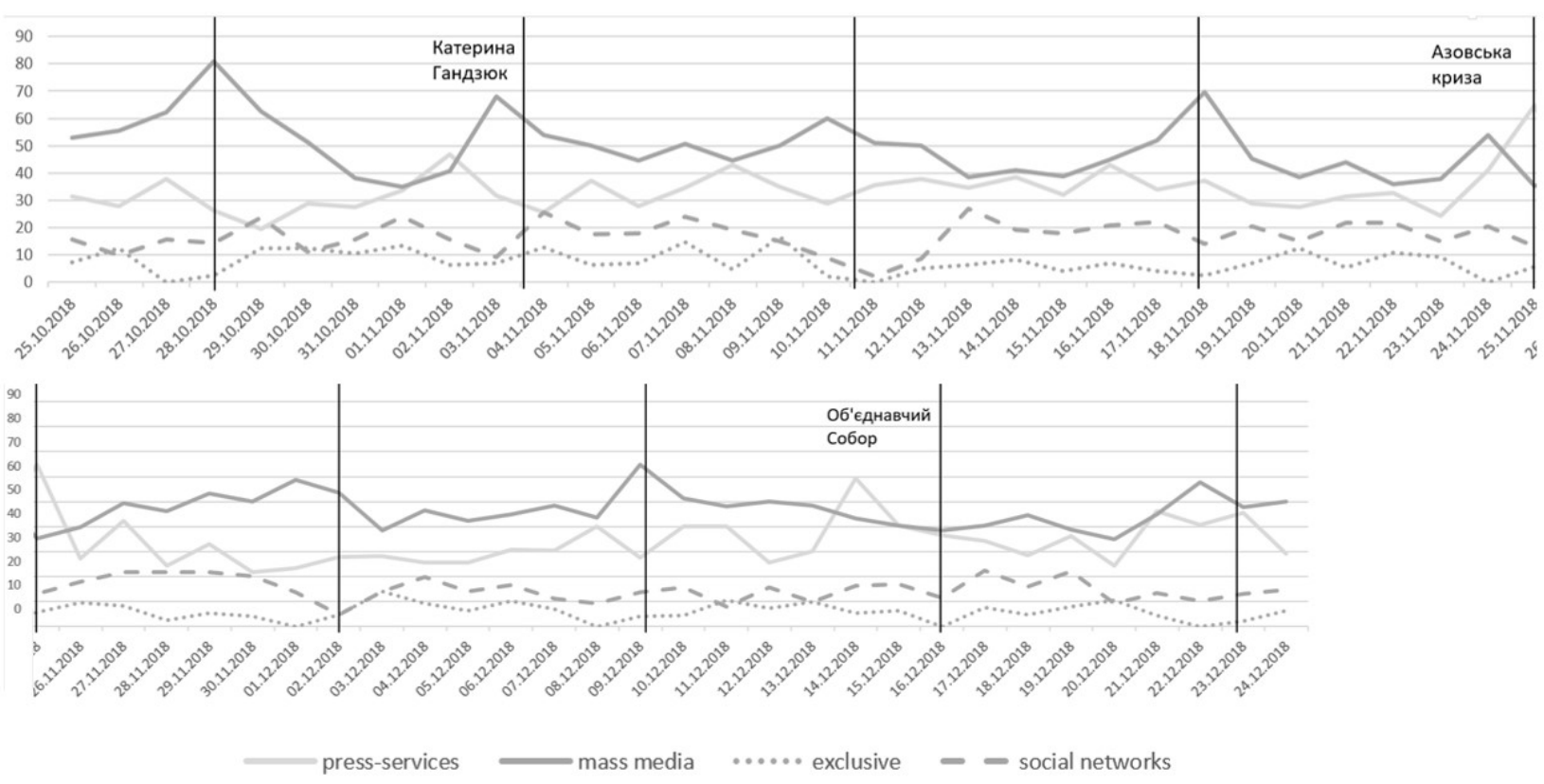

Ми бачимо, що, як правило, передруки із мас-медіа переважають практично увесь час, окрім двох днів за два місяці, коли на перший план виходять прес-служби: 25 листопада i 14 грудня (є ще приблизно однакова кількість повідомлень 2 листопада, коли переважання прес-служб незначне). Тож можемо зробити висновок, що у тлумаченні важливих для країни подій перевага надається саме традиційному каналу передачі інформації. Ще одне спостереження, яке підтверджує висновок, полягає в тому, що кількість повідомлень зі 3МI, зростає, як правило, на вихідні: це й зрозуміло, оскільки в ці періоди активність прес-служб спадає. Проте оскільки цифровий політичний дискурс передбачає роботу 24/7 - тож не може бути й дня без новин - то саме повідомлення зі ЗМІ беруться за основу. Так от якраз у ці два тижні (коли відбулися «Азовська криза» та Об’єднавчий собор), не спостерігаємо звичного підвищення кількості повідомлень зі ЗМІ: перед «Азовською кризою» у суботу 24 листопада почалося зростання, але вже наступного дня повідомлення прес-служб витіснили повідомлення ЗМІ. 
Цікаво, що у ці дні ми не спостерігаємо й зростання ексклюзивних повідомлень: тобто фактично діє розрахунок саме на повідомлення традиційними каналами.

Є також три дні, коли кількість повідомлень із соціальних мереж була приблизно однаковою із кількістю повідомлень прес-служб (в інші періоди останні - значно переважають). Це 29 жовтня, 4 та 30 листопада.

Частина повідомлень від 29 жовтня стосуються терактів у Парижі, а також - падіння літака в Індонезії. Фактично, йдеться про дві гарячі події, що сталися за кордоном і сформували інформаційну картину дня. 4 листопада померла громадська активістка Катерина Гандзюк. 30 листопада, як i упродовж усього тижня, відбувалося обговорення Азовської кризи, долі полонених моряків.

Характер посилань на соціальні мережі у цих трьох випадках різнився. Якщо у першому випадку посилалися на сторінки зарубіжних мас-медіа чи прес-служб. То у другому різноманіття джерел було ширшим. Практично кожне повідомлення, що стосувалося теми, містило лінк на соцмережу. Це були сторінки «Хто замовив Катю Гандзюк?», Т. Печончик, голова правління Центру інформації про права людини, П. Порошенка, Й. Гана (єврокомісар), С. Князєв (керівник Нацполіції). Фактично, тільки у цьому випадку до цифрового політичного дискурсу були включені не тільки статусні джерела (високопосадовці чи політики), але й активісти. Якщо ж говорити про третій випадок, то тут якраз упродовж усього тижня цитували якраз статусні джерела (українські та зарубіжні).

Висновки і перспективи подальших досліджень. Таким чином, ми бачимо, що в українському цифровому політичному дискурсі використовуються переважно традиційні канали передачі інформації. I тут щодо значного переважання 3MI, до того ж, на тлі низького відсотка власних повідомлень хочеться зазначити, що мас-медіа більше займалися поширенням популярних повідомлень, ніж генеруванням власного контенту, за допомогою якого могли б здійснюватися традиційні функції контролю, 
критики та ін. Фактично, велика кількість цитувань ЗМІ наочно демонструє величезний обсяг інформації, наявний у дискурсі. Список же позицій масмедіа нараховує близько 500 позицій (місцевих, загальноукраїнських та міжнародних 3МI). I збільшення використання саме ЗМІ як каналів передачі інформації під кінець тижня якраз і говорить про те, що у цифровій реальності важливий не сам зміст повідомлення, а просто факт наявності повідомлення (Bodrijyar, 2000).

Друга позиція, яку посідають повідомлення прес-служб, говорить про значну перевагу, яку в цифровому дискурсі мають статусні політичні актори. Тим не менш, і вони часто «губляться» в інформаційному шумі - за переваги передруків із мас-медіа. Лише під час масштабних подій - таких, як Азовська криза чи Об’єднавчий собор, вони виходять на перший план, а отже, можуть формувати порядок денний.

Якщо ж говорити про соціальні мережі, то поки що ми не бачимо їхнього переважання у дискурсі - i тенденцій до збільшення присутності саме цього каналу передачі інформації. До того ж, використання соцмереж як каналу, не говорить про переважання у дискурсі нестатусних політичних акторів.

У подальших дослідженнях важливо буде, по-перше, відстежити подальшу динаміку використання традиційних i нових каналів передачі інформації у цифровому дискурсі, аби зрозуміти, коли і за яких обставин відбуваються зміни, а по-друге, зазирнути в історію - і встановити, чи завжди розподіл уваги був саме таким: значне переважання ЗМI - і зовсім незначний відсоток власних повідомлень. Це дасть змогу краще зрозуміти функціонування українського політичного дискурсу у цифрові часи.

\section{ЛIТЕРАТУРА}

1. Бодрийяр, Ж. 2000. Прозрачность зла. Москва: Добросвет.

2. Дейвіс, Н. 2011. Новини пласкої землі. Київ: Темпора.

3. Флах, К. Г. 2015. Влада $i$ злиденність преси. Київ: Академія української преси,

\section{REFERENCES}

1. Bodrijyar, Zh. 2000. Prozrachnost zla. Moskva: Dobrosvet.

2. Deivis, N. 2011. Novyny plaskoi zemli. Kyiv: Tempora.

3. Flakh, K. H. 2015. Vlada i zlydennist presy. Kyiv: Akademiia ukrainskoi presy, Tsentr 
Центр вільної преси.

4. Штромайєр, Г. 2008. Політика і мас-медіа. Київ: Києво-Могилянська акад.

5. Bossetta, M. 2018. The Digital Architectures of Social Media: Comparing Political Campaigning on Facebook, Twitter, Instagram, and Snapchat in the 2016 U.S. Election. Journalism \& Mass Communication Quarterly, 95(2), p. 471-496.

6. Broersma, M. and Graham, T. S. 2013. Twitter as a news source: How Dutch and British newspapers used tweets in their news coverage, 2007-2011. Journalism Practice, 7(4), p. 446-464.

7. Cappelletti, A. 2019. Between Centrality and Re-scaled Identity: A New Role for the Chinese State in Shaping China's Image Abroad: The Case of the Twitter Account. Chin. Polit. Sci. Rev, 4(3), p. 349-374.

8. Chadwick, A. 2011. The Political Information Cycle in a Hybrid News System: The British Prime Minister and the "Bullygate" Affair. International Journal of Press/Politics, 1(16), p. 3-29.

9. Deuze, M. 2004. The Web and its Journalists: considering the consequences of different types of news media online. New Media \& Society, 2(5), p. 203-230.

10. Garcia-Ortega, C. and Zugasti-Azagra, R. 2018. The management of the candidates' Twitter accounts in the Spanish 2016 general elections: Between self-referentiality and media hybridization. El Profesional de la Información, 27(6), p. 1215-1224.

11. Gibson, J. 2017. A crisis of relevance. Columbia Journalism Review [online]. Available at:

https://www.cjr.org/special_report/newsjanine-gibson-newspapers-audience.php [Accessed 04 November 2019].

12. Heiss, R., von Sikorski C. and Matthes, J. Populist Twitter Posts in News Stories: Statement Recognition and the Polarizing Effects on Candidate Evaluation and AntiImmigrant Attitudes. Journalism Practice, 13, p. 20-38.

13. Iggers, J. 1999. Good News, Bad News. Journalism. Ethics and the Public Interest. Boulder, Colo.: Westview Press.

14. Matuszewski, P. and Szabó, G. 2019. Are Echo Chambers Based on Partisanship? Twitter and Political Polarity in Poland and Hungary. Social Media + Society [online]. Available at: https://doi.org/10.1177/2056305119837671 [Accessed 04 November 2019].

15. McGranahan, C. 2019. A Presidential Archive vilnoi presy.

4. Shtromaiier, H. 2008. Polityka i mas-media. Kyiv: Kyievo-Mohylianska akad.

5. Bossetta, M. 2018. The Digital Architectures of Social Media: Comparing Political Campaigning on Facebook, Twitter, Instagram, and Snapchat in the 2016 U.S. Election. Journalism \& Mass Communication Quarterly, 95(2), p. 471-496.

6. Broersma, M. and Graham, T. S. 2013. Twitter as a news source: How Dutch and British newspapers used tweets in their news coverage, 2007-2011. Journalism Practice, 7(4), p. 446-464.

7. Cappelletti, A. 2019. Between Centrality and Re-scaled Identity: A New Role for the Chinese State in Shaping China's Image Abroad: The Case of the Twitter Account. Chin. Polit. Sci. Rev, 4(3), p. 349-374.

8. Chadwick, A. 2011. The Political Information Cycle in a Hybrid News System: The British Prime Minister and the "Bullygate" Affair. International Journal of Press/Politics, 1(16), p. 3-29.

9. Deuze, M. 2004. The Web and its Journalists: considering the consequences of different types of news media online. New Media \& Society, 2(5), p. 203-230.

10. Garcia-Ortega, C. and Zugasti-Azagra, R. 2018. The management of the candidates' Twitter accounts in the Spanish 2016 general elections: Between self-referentiality and media hybridization. El Profesional de la Información, 27(6), p. 1215-1224.

11. Gibson, J. 2017. A crisis of relevance. Columbia Journalism Review [online]. Available at: https://www.cjr.org/special_report/newsjanine-gibson-newspapers-audience.php [Accessed 04 November 2019].

12. Heiss, R., von Sikorski C. and Matthes, J. Populist Twitter Posts in News Stories: Statement Recognition and the Polarizing Effects on Candidate Evaluation and AntiImmigrant Attitudes. Journalism Practice, 13, p. 20-38.

13. Iggers, J. 1999. Good News, Bad News. Journalism. Ethics and the Public Interest. Boulder, Colo.: Westview Press.

14. Matuszewski, P. and Szabó, G. 2019. Are Echo Chambers Based on Partisanship? Twitter and Political Polarity in Poland and Hungary. Social Media + Society [online]. Available at: https://doi.org/10.1177/2056305119837671 [Accessed 04 November 2019].

15. McGranahan, C. 2019. A Presidential 
of Lies: Racism, Twitter, and a History of the Present. International Journal of Communication, 13, p. 3164-3182.

16. McLaughlin, B. Becoming a Presidential Candidate: Social Media Following and Politician Identification. Mass Communication and Society, 22(5), p. 584-603.

17. Ott, B. L. 2017. The age of Twitter: Donald J. Trump and the politics of debasement. Critical Studies in Media Communication, 34(1), p. 59-68.

18. Pérez-Curiel, C. and Naharro, P. L. 2019. Political influencers. A study of Donald Trump's personal brand on Twitter and its impact on the media and users. Comunicacion y Sociedad, 32(1), p. 57-76.

19. Schneiker, A. 2019. Telling the Story of the Superhero and the Anti-Politician as President: Donald Trump's Branding on Twitter. Political Studies Review, 17(3), p. 210-223.

20. Steensen, S. 2011. Online Journalism and Promises of New Technology. Journalism Studies, 12 (3), p. 311-327.

21. Stetka, V. and Surowiec, P. 2019. Facebook as an Instrument of Election Campaigning and Voters' Engagement: Comparing Czechia and Poland. European Journal of Communication, 34(2), p. 121-141.

22. Suárez, E. 2018. "The present crisis of Western democracy is a crisis of journalism". Nieman Reports [online]. Available at: https://nieman.harvard.edu/articles/thepresent-crisis-of-western-democracy-is-acrisis-of-journalism/ [Accessed 04 November 2019].

23. Thompson, M. 2016. Enough Said: What's Gone Wrong with the Language of Politics? New York : St. Martin's Press.

24. Villar, S. and María, J. The use of blogs as social media tools of political communication: citizen journalism and public opinion 2.0. Communication \& Society, 32(1), p. 39-55.
Archive of Lies: Racism, Twitter, and a History of the Present. International Journal of Communication, 13, p. 3164-3182.

16. McLaughlin, B. Becoming a Presidential Candidate: Social Media Following and Politician Identification. Mass Communication and Society, 22(5), p. 584603.

17. Ott, B. L. 2017. The age of Twitter: Donald J. Trump and the politics of debasement. Critical Studies in Media Communication, 34(1), p. 59-68.

18. Pérez-Curiel, C. and Naharro, P. L. 2019. Political influencers. A study of Donald Trump's personal brand on Twitter and its impact on the media and users. Comunicacion y Sociedad, 32(1), p. 57-76.

19. Schneiker, A. 2019. Telling the Story of the Superhero and the Anti-Politician as President: Donald Trump's Branding on Twitter. Political Studies Review, 17(3), p. 210-223.

20. Steensen, S. 2011. Online Journalism and Promises of New Technology. Journalism Studies, 12 (3), p. 311-327.

21. Stetka, V. and Surowiec, P. 2019. Facebook as an Instrument of Election Campaigning and Voters' Engagement: Comparing Czechia and Poland. European Journal of Communication, 34(2), p. 121-141.

22. Suárez, E. 2018. "The present crisis of Western democracy is a crisis of journalism". Nieman Reports [online]. Available at: https://nieman.harvard.edu/articles/thepresent-crisis-of-western-democracy-is-acrisis-of-journalism/ [Accessed 04 November 2019].

23. Thompson, M. 2016. Enough Said: What's Gone Wrong with the Language of Politics? New York : St. Martin's Press.

24. Villar, S. and María, J. The use of blogs as social media tools of political communication: citizen journalism and public opinion 2.0. Communication \& Society, 32(1), p. 39-55.

\section{Інформація про автора}

Стеблина Наталія Олександрівна - кандидат наук із соціальних комунікацій, доцент Донецький національний університет імені Василя Стуса; докторант кафедри політології і державного управління м. Одеса; e-mail: n.steblyna@donnu.edu.ua; ORCID ID: https://orcid.org/0000-0001-9799-9786; 